\title{
Adenocarcinoma of the small bowel as a complication of Crohn's disease
}

\author{
J. D. FRANK AND B. A. SHOREY \\ From the Royal United Hospital, Combe Park, Bath
}

SUMMARY Two cases of adenocarcinoma of the bowel occurring in association with Crohn's disease are described. The first affected the terminal ileum and the second the terminal ileum and caecum. The 28 cases so far described in the world literature are briefly reviewed. It is suggested that adenocarcinoma of the small bowel may be a complication of longstanding Crohn's disease. Eleven patients developed the carcinoma in a surgically bypassed segment of bowel, and it is therefore recommended that where surgery is undertaken excision rather than bypass should be the treatment of choice.

\section{Case 1}

Mr L.W. presented in 1957 at the age of 33 with the signs and symptoms of acute appendicitis. At operation the appendix was normal but the terminal 18 in. of ileum was thickened, oedematous, and inflamed. A clinical diagnosis of Crohn's disease was made and an ileo-transverse colostomy performed.

For 13 years he was fairly well with only occasional attacks of diarrhoea and abdominal pain. In December 1970 he presented with abdominal pain, fever, bleeding per rectum, and diarrhoea. Examination revealed a mass in the right iliac fossa. Barium meal and follow-through showed stenosis of the ileo-transverse anastomosis and a grossly contracted terminal ileum between the anastomosis and the caecum. His symptoms settled with conservative therapy but by February 1972 they had progressed and a laparotomy was performed.

At operation a grossly thickened and indurated terminal ileum was found. There was marked fibrosis around the ileo-transverse anastomosis and the ileum proximal to this was dilated. The other viscera appeared normal. A right hemicolectomy was performed, together with excision of the diseased ileum, and the continuity of bowel was restored with an end-to-end anastomosis.

Macroscopically the specimen consisted of terminal ileum $(50 \mathrm{~cm})$ with the caecum and colon $(30 \mathrm{~cm})$ and an old ileo-transverse anastomosis. There was a stenosing white tumour of the ileum, $2 \mathrm{~cm}$ proximal

Received for publication 22 November 1972.



Fig. 1 Adenocarcinoma infiltrating muscle wall of ileum (haematoxylin and eosin $\times 40$ ). 


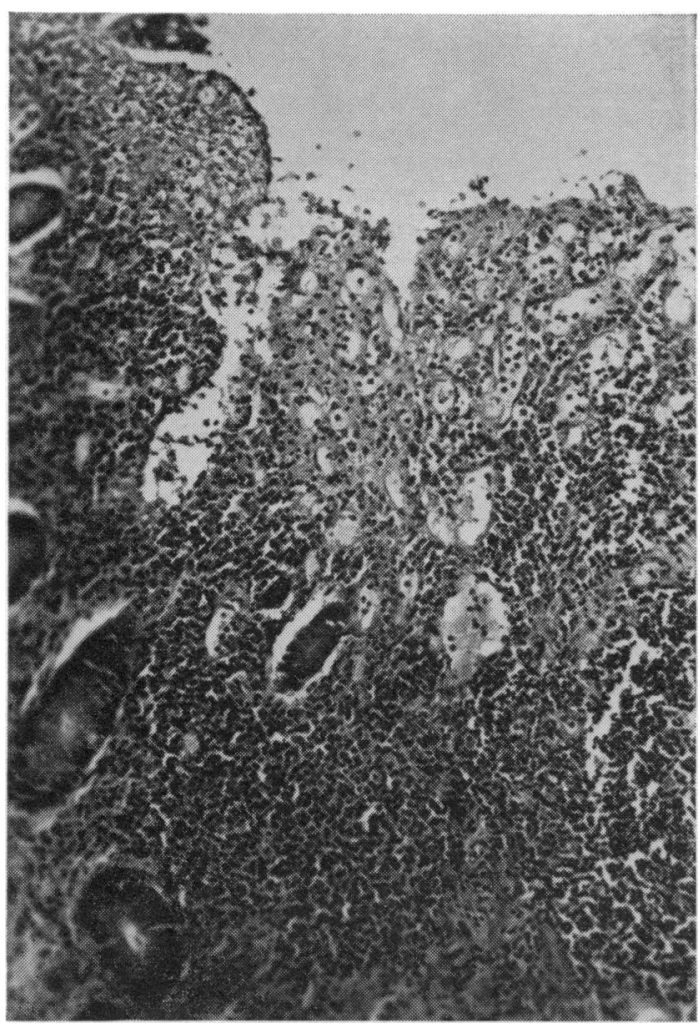

Fig. 2 Non-neoplastic chronic ulceration at anastomosis (haematoxylin and eosin $\times 40$ ).

to the ileo-caecal valve and extending for $11 \mathrm{~cm}$ proximally. On histological examination this tumour was seen to be an adenocarcinoma of the terminal ileum (Fig. 1). No tumour was present at the ileotransverse anastomosis but there was chronic ulceration with fissuring consistent with Crohn's disease (Fig. 2).

\section{Case 2}

Mrs. L.K. presented in 1960 at the age of 42 with subacute, small bowel obstruction and a four-year history of intermittent abdominal pain and diarrhoea. At operation a 6 in. area of terminal ileum was found to be thickened and contracted, and the bowel proximal to this was grossly dilated. A clinical diagnosis of Crohn's disease was made and an ileotransverse colostomy performed.

In May 1967 she suffered a severe exacerbation of her symptoms and underwent laparotomy. Three skip lesions of Crohn's disease were found, 3 in. and 6 in. from the ileo-caecal valve and 5 in. from the duodeno-jejunal flexure. These were excised and the

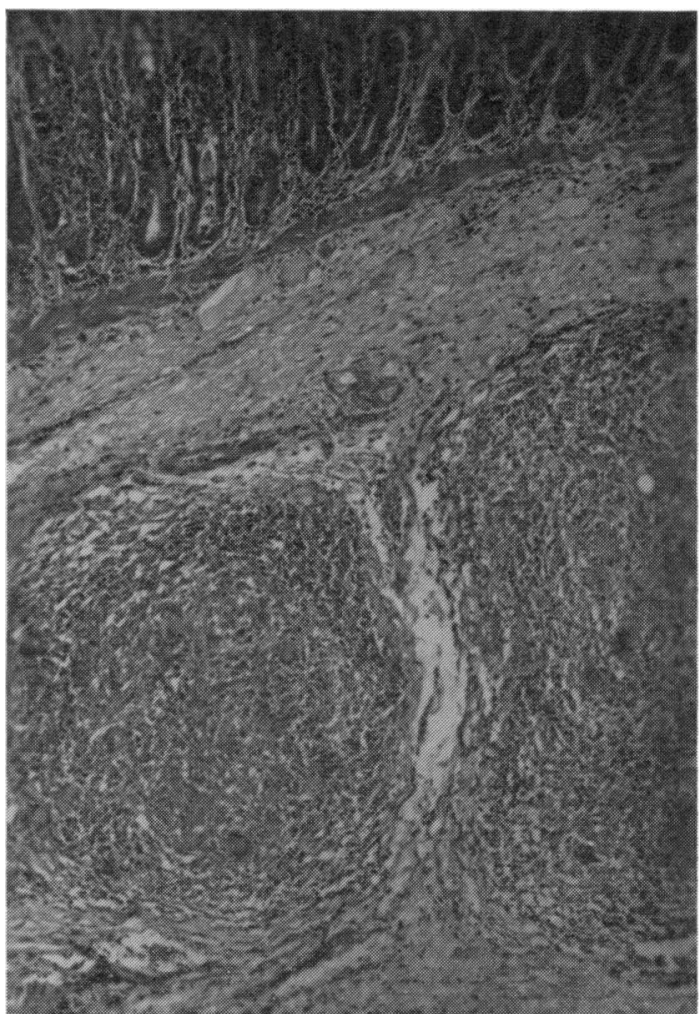

Fig. 3 Epithelioid follicles in wall of small intestine (haemotoxylin and eosin $\times 65$ ).

ileo-transverse colostomy was disconnected. Histological examination of the resected lesions showed the classical features of Crohn's disease (Fig. 3). She remained in moderate health on conservative therapy until June 1971. She then suffered a relapse and a barium meal at that time showed a filling defect in the medial border of the proximal part of the ascending colon with an abnormal terminal ileum. At operation in February 1972 a hard mass was found in the right iliac fossa which consisted of a grossly contracted and thickened terminal ileum coiled upon itself. It was adherent to an abnormally thickened caecum, and the regional lymph nodes were hard and enlarged. The liver was normal. A right hemicolectomy with end-to-end anastomosis was performed.

Macroscopic examination of the specimen showed that it consisted of colon and caecum $(30 \mathrm{~cm})$ and adherent loops of terminal ileum $(24 \mathrm{~cm})$. There was a white, hard growth involving the terminal ileum, ileo-caecal valve, caecum, and part of the ascending colon. Histologically there was no evidence of active Crohn's disease. The tumour proved to be an extensive columnar-celled adenocarcinoma involving 


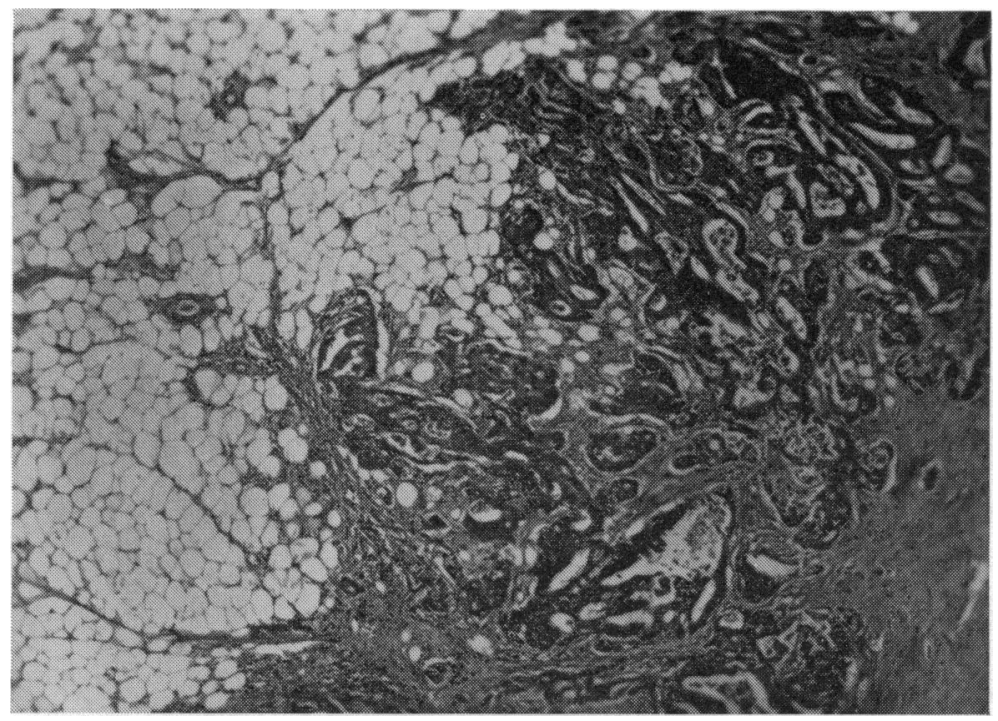

Fig. 4 Ileo-caecal adenocarcinoma infiltrating mesenteric fat (haematoxylin and $\operatorname{eosin} \times 40)$.

\begin{tabular}{|c|c|c|c|c|c|c|c|c|}
\hline Year & Author & $\begin{array}{l}\text { Age at } \\
\text { Diagnosis } \\
\text { of } \\
\text { Carcinoma }\end{array}$ & Sex & $\begin{array}{l}\text { Symptoms } \\
(y r)\end{array}$ & Tumour & Crohn's & Diagnosis & Outcome after Operation \\
\hline $\begin{array}{l}1956 \\
1957 \\
1958\end{array}$ & $\begin{array}{l}\text { Ginzburg et al } \\
\text { Kornfield et al } \\
\text { Crohn and Yarnia }\end{array}$ & $\begin{array}{l}30 \\
36 \\
-\end{array}$ & $\begin{array}{l}\mathbf{M} \\
\mathbf{F} \\
-\end{array}$ & $\begin{array}{r}19 \\
8 \\
\end{array}$ & $\begin{array}{l}\text { Jejunum } \\
\text { Jejunum } \\
\text { Jejunum }\end{array}$ & $\begin{array}{l}\text { Jejunum } \\
\text { Jejunum } \\
\text { Jejunum \& } \\
\text { ileum }\end{array}$ & $\begin{array}{l}\text { Postoperative } \\
\text { At surgery } \\
-\end{array}$ & $\begin{array}{l}\text { Died } 6 / 12, \text { metastases } \\
\text { Died } 6 / 12, \text { metastases } \\
-\end{array}$ \\
\hline 1958 & Bersack et al & 26 & $\mathbf{M}$ & 9 & $\begin{array}{l}\text { Duodenum, } \\
\text { jejunum, } \\
\text { colon }\end{array}$ & Ileum & Necropsy & Died 4/52 \\
\hline 1958 & Lear & 一 & 一 & 一 & Ileum & Ileum & Postoperative & - \\
\hline 1959 & Buchanan et al & 47 & $\mathbf{M}$ & 28 & Ileum & Ileum & Postoperative & 一 \\
\hline 1959 & Weingarten et al & 44 & $\mathbf{F}$ & 27 & Jejunum ${ }^{1}$ & Jejunum & Postoperative & Died 4/12, metastases \\
\hline 1960 & Weingarten and Weiss & 28 & $\mathbf{F}$ & 5 & Ileum ${ }^{1}$ & $\begin{array}{l}\text { Jejunum \& } \\
\text { ileum }\end{array}$ & At surgery & Died 3 years, metastases \\
\hline 1960 & Zisk et al & 61 & $\mathbf{F}$ & $1 / 52$ & Ileum & Ileum & Postoperative & Died $2 / 52$, pulmonary embolism \\
\hline 1960 & Zisk et al & 62 & $\mathbf{F}$ & 25 & Ileum ${ }^{1}$ & Ileum & Preoperative & - \\
\hline 1960 & Steele and McNeely & 38 & $\mathbf{M}$ & 15 & Ileum 1 & Ileum & Necropsy & - \\
\hline 1960 & Almond et al & 48 & $\mathbf{F}$ & 15 & Ileum & Ileum & Postoperative & - \\
\hline 1963 & Hoeffert et al & 40 & $\mathbf{M}$ & 1.5 & Ileum & Ileum & Postoperative & Died 2 years, metastases \\
\hline 1964 & Berman and Prior & 51 & $\mathbf{M}$ & 25 & Ileum & Ileum & Postoperative & $\begin{array}{l}\text { Alive \& well immediately after } \\
\text { operation }\end{array}$ \\
\hline 1968 & Cantwell et al & 60 & $\mathbf{M}$ & 31 & Ileum & Ileum & Postoperative & Died 4 days, metastases \\
\hline 1968 & Shiel et al & 40 & $\mathbf{F}$ & 5 & Ileum & Ileum & Postoperative & Died $16 / 12$, metastases \\
\hline 1968 & Morovitch et al & 41 & $\mathbf{M}$ & 22 & Ileum & Ileum & Postoperative & Died $4 / 12$, metastases \\
\hline 1969 & Tyers et al & 32 & $\mathbf{M}$ & 12 & Jejunum ${ }^{1}$ & Jejunum \& & Postoperative & Died $3 / 12$, metastases \\
\hline 1969 & Wyatt & 31 & $\mathbf{M}$ & 7 & Ileum & Jleum & Postoperative & Died 1 day, bronchopneumonia \\
\hline 1969 & Magnes and Bell & 71 & $\mathbf{M}$ & 11 & Ileum & Ileum & Postoperative & - \\
\hline 1970 & Farmer et al & 43 & $\mathbf{M}$ & 9 & Jejunum ${ }^{1}$ & Jejunum & Postoperative & Died 7/12 \\
\hline 1970 & Farmer et al & 61 & $\mathbf{F}$ & 7 & Jejunum & Jejunum & Postoperative & $\begin{array}{l}\text { Died } 3 / 12 \text {, metastases and pulmon- } \\
\text { ary embolism }\end{array}$ \\
\hline 1970 & Brown et al & 55 & $\mathbf{F}$ & 25 & Ileum ${ }^{1}$ & Ileum & Postoperative & Died $1 / 12$ \\
\hline 1970 & Goldman et al & 21 & $\mathbf{F}$ & 9 & Jejunum & $\begin{array}{l}\text { Jejunum \& } \\
\text { ileum }\end{array}$ & Postoperative & - \\
\hline 1970 & Schuman & 48 & $\mathbf{M}$ & 7 & Ileum & Ileum & Postoperative & - \\
\hline 1970 & Rha et al & 38 & $\mathbf{M}$ & $5 / 12$ & Ileum & Ileum & Postoperative & Alive and well, $6 / 12$ \\
\hline 1972 & Schofield & 20 & $\mathbf{M}$ & 7 & Ileum & Ileum & At surgery & Died 2 years, metastases \\
\hline 1972 & Schofield & 20 & $\mathbf{M}$ & 4 & Ileum 1 & Ileum & At surgery & Died few months, metastases \\
\hline 1972 & Frank & 48 & $\mathbf{M}$ & 15 & Ileum ${ }^{1}$ & Ileum & Postoperative & Alive and well, $3 / 12$ \\
\hline 1972 & Frank & 55 & $\mathbf{F}$ & 16 & Ileo-caecal ${ }^{1}$ & lleum & Postoperative & Alive and well, $3 / 12$ \\
\hline 1973 & Frank and Shorey pres & nt series & & & & & & \\
\hline
\end{tabular}

Table I Recorded cases in the literature of small bowel adenocarcinoma associated with Crohn's disease ${ }^{1}$ Bypassed segment of bowel 
the ileo-caecal region and infiltrating the mesenteric fat (Fig. 4).

\section{Discussion}

The first case of an adenocarcinoma of the small bowel occurring in association with Crohn's disease was reported by Ginzburg, Schneider, Dreizin, and Levinson in 1956, 24 years after the original description of the disease as a pathological entity (Crohn, Ginzburg, and Oppenheimer, 1932). Over the past 16 years there has been a progressive increase in the number of cases appearing in the literature (Table I), possibly because there is now a greater awareness that an association may exist between these two diseases. The reported incidence of this association is almost certainly low, due to the fact that a small carcinoma may easily be overlooked. Multiple sections must be taken and the specimen examined thoroughly before a case of longstanding Crohn's disease is labelled 'no sign of malignancy'.

The diagnostic signs and symptoms of an adenocarcinoma of the small bowel are usually masked by those of Crohn's disease and thus a preoperative diagnosis is virtually impossible. It appears that only Zisk (Zisk, Shore, Rossoff, and Friedman, 1960) has suspected the diagnosis before operation, and his suspicions were aroused because of a previous encounter earlier in the year with a patient in whom the two diseases coexisted.

Significant differences exist in the natural history, pathology, and prognosis of small bowel adenocarcinoma arising in otherwise normal small bowel and adenocarcinoma arising in small bowel which is also the site of Crohn's disease. Table II shows that the latter disease affects a much younger age group, has a worse prognosis, and no five-year survivors have, as yet, been reported. In addition, adenocarcinoma of the small bowel arising in patients with Crohn's disease occurs twice as frequently in the

\begin{tabular}{|c|c|c|}
\hline & $\begin{array}{l}\text { Small Bowel } \\
\text { Adenocarcinoma } \\
\text { Alone }\end{array}$ & $\begin{array}{l}\text { Small Bowel } \\
\text { Adenocarcinoma with } \\
\text { Crohn's Disease }\end{array}$ \\
\hline \multirow{4}{*}{$\begin{array}{l}\text { Average age at } \\
\text { diagnosis } \\
\text { Duration of } \\
\text { symptoms } \\
\text { Site of carcinoma } \\
\text { Reported average } \\
\text { postoperative surviva } \\
\text { Reported five-year } \\
\text { survival }\end{array}$} & $55 \mathrm{yr}$ & $43 \mathrm{yr}$ \\
\hline & $\begin{array}{l}14 \mathrm{mth} \\
\text { Jejunum/ileum } 3^{\prime} 5 / 1\end{array}$ & $\begin{array}{l}12 \mathrm{yr} \\
\mathrm{Jejunum} / \text { ileum } 1 / 2\end{array}$ \\
\hline & $32 \mathrm{mth}$ & $8 \mathrm{mth}$ \\
\hline & $20 \%$ & $\begin{array}{l}0 \text { recorded cases } \\
\text { (inadequate follow-up) }\end{array}$ \\
\hline
\end{tabular}

Table II Comparison of small bowel adenocarcinoma and small bowel adenocarcinoma associated with Crohn's disease ileum than in the jejunum. This is in contrast to adenocarcinoma occurring in patients with otherwise normal small bowel in whom the jejunum is three times more commonly affected than the ileum (Darling and Welch, 1959; Pagtalunan, Mayo, and Dockerty, 1964).

Adenocarcinomas have arisen in bypassed segments of bowel in nine out of the 28 cases so far reported and in both patients described in this paper, although the bypass was disconnected in the second patient five years before the carcinoma was discovered. It appears, therefore, that where surgery for Crohn's disease has to be undertaken, and there are no contraindications to resection, excision of the affected area should be the treatment of choice.

We should like to thank Mr H. T. John and Dr K. R. Gough for their helpful criticism in the preparation of this paper.

\section{References}

Almond, C. H., Neal, M. P., and Moedl, K. R. (1960). Regional ileitis with coincident ileal carcinoma. Missouri Med., 57, 452-453.

Berman, L. G., and Prior, J. T. (1964). Adenocarcinoma of the small intestine occurring in a case of regional enteritis. J. Mt Sinai Hosp., 31, 30-37.

Bersack, S. R., Howe, J. S., and Rehak, E. N. (1958). A unique case with roentological evidence of regional enteritis of long duration with histological evidence of diffuse adenocarcinoma. Gastroenterology, 34, 703-710.

Brown, N., Weinstein, V. A., and Janowitz, H. D. (1970). Carcinoma of the ileum twentyfive years after bypass for regional enteritis: a case report. Mt Sinai J. Med. (N.Y.), 37, 675-677.

Buchanan, D. P., Huebner, G. D., Woolvin, S. C., North, R. L., and Novack, T. D. (1959). Carcinoma of the ileum occurring in an area of regional enteritis. Amer. J. Surg., 97, 336-339.

Cantwell, J. D., Kettering, R. F., Carney, J. A., and Ludwig, J. (1968). Adenocarcinoma complicating regional enteritis: report of a case and review of the literature. Gastroenterology, 54, 599-604.

Crohn, B. B., Ginzburg, L., and Oppenheimer, G. D. (1932). Regional ileitis: a pathologic and clinical entity. J. Amer. med. Ass., 99, 1323-1329.

Crohn, B. B., and Yarnis, H. (1958). Regional Ileitis, 2nd ed., p. 74. Grune and Stratton, New York and London.

Darling, R. C., and Welch, C.E.(1959). Tumors of the small intestine. New Engl. J. Med., 260, 397-408.

Farmer, R. G., Hawk, W. A., and Turnbull, R. B. (1970). Carcinoma associated with regional enteritis: a report of two cases. Amer. J. dig. Dis., 15, 365-371.

Ginzburg, L., Schneider, K. M., Dreizin, D. H., and Levinson, C. (1956). Carcinoma of the jejunum occurring in a case of regional enteritis. Surgery, 39, 347-351.

Goldman, L. I., Bralow, S. P., Cox, W., and Peale, A. R. (1970). Adenocarcinoma of the small bowel complicating Crohn's disease. Cancer (Philad.), 26, 1119-1125.

Hoffert, P. W., Weingarten, B., Friedman, L. D., and Morecki, R. (1963). Adenocarcinoma of the terminal ileum in a segment of bowel with co-existing active ileitis. N.Y. med.J., 63, 1567-1571.

Kornfeld, P., Ginzburg, L., and Adlersberg, D. (1957). Adenocarcinoma occurring in regional jejunitis. Amer. J. Med., 23, 493-498.

Lear, P. E. (1958). The physiological basis for the surgical management of regional enteritis. Surg. Clin. N. Amer., 38, 545-559.

Magnes, M., and DeBell, P.(1969). Carcinoma associated with terminal ileitis. J. med. Soc. N.J., 66, 573-574.

Morowitz, D. A., Block, G. E., and Kirsner, J. B. (1968). Adenocarcinoma of the ileum complicating chronic regional enteritis. Gastroenterology, 55, 397-402.

Pagtalunan, R. J. G., Mayo, C. W., and Dockerty, M. B. (1964). Primary malignant tumours of the small intestine. Amer. J. Surg., 108, 13-18. 
Rha, C. K., Wilson, J. M., Jr., and Klein, N. C. (1971). Adenocarcinoma of the ileum with co-existing regional enteritis. Arch. Surg., $102,630-633$.

Schofield, P. F. (1972). Intestinal malignancy and Crohn's disease. Proc. roy. Soc. Med., 65, 783-784.

Schuman, B. M. (1970). Adenocarcinoma arising in an excluded loop of ileum. New Engl. J. Med., 283, 136-137.

Sheil, F. O., Clark, C. G., and Golligher, J. C. (1968). Adenocarcinoma associated with Crohn's disease. Brit. J. Surg., 55, 53-58.

Steele, D. C., and McNeely, D. T. (1960). Adenocarcinoma arising in a site of chronic regional enteritis. Canad. med. Ass. J., 83, 379-381.

Tyers, G. F. O., Steiger, E., and Dudrick, S. J. (1969). Adenocarcinoma of the small intestine and other malignant tumors complicating regional enteritis. Ann. Surg., 169, 510-518.

Weingarten, B., Parker, J. G., Chazen, E. M., and Jacobson, H. G. (1959). Adenocarcinoma of the jejunum in nonspecific granulomatous enteritis. Arch. Surg., 78, 483-489.

Weingarten, B., and Weiss, J. (1960). Malignant degeneration in chronic inflammatory disease of the colon and small intestine. Amer. J. Gastroent., 33, 203-207.

Wyatt, A. P. (1969). Regional enteritis leading to carcinoma of the small bowel. Gut, 10, 924-927.

Zisk, J., Shore, J. M., Rosoff, L., and Friedman, N. B. (1960). Regional ileitis complicated by adenocarcinoma of the ileum: a report of two cases. Surgery, 47, 970-974.

\section{The January 1973 Issue}

\section{THE JANUARY 1973 ISSUE CONTAINS THE FOLLOWING PAPERS}

Ultrastructural changes suggestive of immune reactions in the jejunal mucosa of coeliac children following gluten challenge MARGOT SHINER

The response to prednisolone in atrophic gastritis: a possible effect on non-intrinsic factor-mediated vitamin $B_{12}$ absorption R. G. STRICKLAND, JUNE M. FISHER, K. LEWIN, AND K. B. TAYLOR

Lymphocyte transformation in the mesenteric lymph nodes of patients with Crohn's disease P. J. GUILLOU, T. G. BRENNAN, AND G. R. GILES

Zollinger-Ellison syndrome type 1: clinical and pathological correlations in a case D. J. COWLEY, I. W. DYMOCK, B. E. BOYES, R. Y. WILSON, B. H. STAGG, M. R. LEWIN, JULiA M. POLAK, AND A. G. E. PEARSE

The role of thoracic duct lymph in gastrin transport and gastric secretion B. GUY CLENDINNEN, DAVID D. REEDER, AND JAMES C. THOMPSON

Some observations on the intrinsic nervous mechanism in Hirschsprung's disease G. M. FRIGO, M. DEL TACCA, S. LECCHINI, AND A. CREMA

The effect of amino acids and dipeptides on sodium and water absorption in man M. D. HELLIER, C. THIRUMALAI, AND C. D. HOLDSWORTH
Inheritance of type 2 Crigler-Najjar hyperbilirubinaemia J. O. HUNTER, R. P. H. THOMPSON, P. M. DUNN, AND ROGER WILLIAMS

The use of combined ultrasonic and isotope scanning in the diagnosis of amoebic liver disease A. W. MATTHEWS, K. R. GOUGH, E. RHYS DAVIES, F. G. M. ROSS, AND A. HINCHLIFFE

Exocrine secretory responses of the pancreas to insulin and to a meat meal in dogs S. GUPTA, J. B. ELDER, AND A. W. KAY

Treatment of bleeding oesophageal varices by infusion of vasopressin into the superior mesenteric artery IAIN M. MURRAY-LYON, R. N. H. PUGH, H. B. NUNNERLEY, J. W. LAWS, J. L. DAWSON, AND ROGER WILLIAMS

Ischaemic colitis and abdomino-perineal excision of the rectum M. LEA THOMAS AND J. M. WELLWOOD

\section{Technique}

Cholecystectomy cholangiogram snare HAMISH THOMSON

Progress report

Dietary fibre J. H. CUMMINGS

Notes and activities 